\title{
Analysis of Endonuclease activity in clinically and Environmental originated vibrio species
}

\author{
Mohamed Salem Khalifa Aljwadi ${ }^{1}$, Sapna Smith Lal ${ }^{2 *}$ \\ ${ }^{1}$ MSC, MLT scholar, Sam Higginbottom University of Agriculture, Technology and Sciences, U.P., India \\ ${ }^{2}$ Asst. professor (sel. Grade), Faculty of Health and Medical Science, Sam Higginbottom University of \\ Agriculture, Technology and Sciences, U.P., India
}

Received: 20-08-2019 / Revised: 13-11-2019 / Accepted: 19-11-2019

\begin{abstract}
The research under given depicts the study vibrio species taken from faecal and environmental source. It is well known through researches that environment possess a very dense presence of cholera causing vibrio strains and that only a certain subsets of the strains are associated with human disease. The difference in the genetic profile of the clinical strains of the Vibrio species compared with their environmental counterparts was here exploited to trace specific human isolates to vectors of disease and also to allow a better estimation of whether a particular genotype is more often associated with disease or not. Isolation of Vibrio species was performed by taking water sample from river and Faecal matter they were cultured on TCBS Agar plate further they were screened through their biochemical properties. 6 different isolates were chosen to sonicate and bring up the lysates in order to obtain to assay their endonuclease activity, In every nook and cranny endonuclease activity was possessed by each and every isolate1_FS were in 13 fragments ,2 _WS in 10 fragments ,3_FS in 11 fragments. Thus it gave comparative assessment of Restriction endonuclease pattern.
\end{abstract}

Key words: Vibrio Cholerae, Faecal sample, Water samples, Lysates, Endonuclease activity

(C) The Author(s). 2019 Open Access. This work is licensed under a Creative Commons Attribution. The full terms of this license are available at our website and incorporate the Creative Commons Attribution. https://creativecommons.org/licenses/by/4.0/

\section{INTRODUCTION}

In the thick of Vibrionaceae, $V$. choleraeis in contemplation with respect to human disorders health and disease. It is a gram-negative marine bacterium, and a human intestinal pathogen which resides in both brackish and sea water. ${ }^{[1]}$ While others may not be responsible for the cholera disease vibrios are responsible in synthesizing varied factors which are present extracellularly. These factors including Cyto toxic, enterotoxin, hemolysis, protease, collagenase, phospholipase, siderophore, and hemagglutinin. ${ }^{[2]}$

\section{*Corresponding Author}

Dr. Sapna Smith Lal

Asst. Professor (sel. Grade), Faculty of Health and Medical Science, Sam Higginbottom University of Agriculture, Technology and Sciences, U.P., India.

E-mail: husienaljwadi@gmail.com
The hydrolyzing property of proteolytic enzyme for proteins and peptides is well known essential for the homeostatic control in both eukaryotes and prokaryotes, and thus, the enzymes coalesced by bacteria are responsible for their internal function could be damageable to the host they are infection. ${ }^{[3,4]}$

Restriction endonuclease are unquestionable factor of Vibro species. Restriction endonuclease enzyme produced chiefly by certain bacteria that has the property of cleaving DNA molecules at or near a specific sequence of bases. Some of the bacteria are majorly responsible for production enzymes that cleave sugar - phosphate backbone present in DNA strands. They are also responsible for carrying out host-defense mechanism function in cells. The enzymes are responsible. Enzymes recognize a specific DNA base sequence and are responsible for cleaving near restriction endonuclease Restriction endonucleases are responsible for recognizing the specific location in DNA where they cleave the strands of double stranded DNA. ${ }^{[5]}$

Aljwadi and Lal
$\begin{aligned} & \text { www.apjhs.com } \\ & \text { Asian Pacific Journal of Health Sciences, 2019;6(4):5-10 }\end{aligned}$




\section{MATERIALS AND METHOD}

For the isolation of different species of Vibrio cholerae Water samples were collected from the Gomti river of Lucknow near the river side park the samples were collected from the flowing water at a distance $15 \mathrm{~m}$ from each other. The water samples were spread at the dilution of $10^{-6}$ on TCBS agar plates. ${ }^{[13]}$ TCBS Agar is generally recommended by APHA for the selective isolation of $V$. cholerae and V.parahaemolyticus. ${ }^{[6,7]}$ Enrichment in Alkaline Peptone Water (M618), followed by isolation on TCBS Agar are routinely acknowledged for the isolation of V.cholerae. Out of four samples 6 isolates were chosen depending upon their relative different colonies.

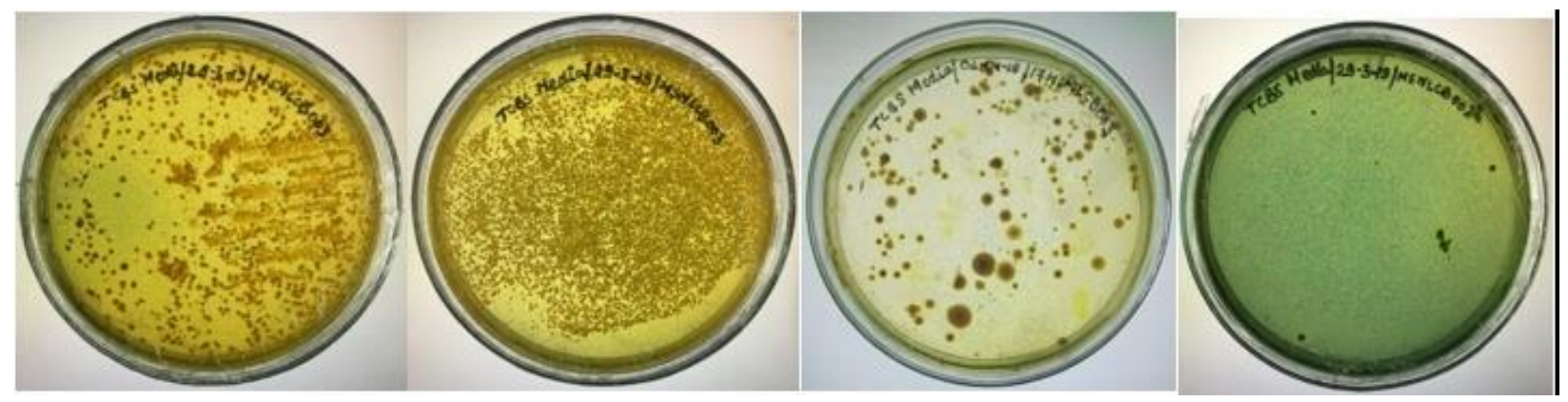

Fig 1: Depicts the spreading of water and faecal sample over the TCBS agar

6 loop full of cultures were taken from the spread Agar plate and thereafter streaked out on TCBS agar plate (Hi media) for peculiar results. After which 0.5 to 3 $\mathrm{mm}$ broad colony obtained over TCBS agar plate was inoculated on the Luria-Bertani broth containing $2 \%$ $\mathrm{NaCl}$. This purified culture was further used different Biochemical tests[Fig 1]

\section{Biochemical Tests}

All together 6 Biochemical tests were performed in order to identify Vibrio species. The modus implemented for the arginine dihydrolase test was on the grounds of Thornley's method. ${ }^{[8]}$ The medium used was Luria-Bertani broth containing $1 \%$ (wt/vol) Larginine ( $\mathrm{pH}$ 6.8). Phenol red powder (Rankem) was brought in use as indicator. Soon After inoculation, the tubes were covered with paraffin wax and was then incubated at $37^{\circ} \mathrm{C}$ for $24 \mathrm{~h}$. Appearance of red colour was considered a positive reaction. The sugar fermentation tests of Sucrose and Glucose was also performed using Sugar Fermentation broth (Himedia). Indole producing capabilities of microbes were determined by the modus that the suspension from a culture grown on nutrient broth (Himedia) is incubated with tryptophan, indole is formed fairly rapidly and can be detected by any of the indole test reagents. Kovack's reagent was preferred to Bohme's as the results were easier to read and only one solution was needed. Referred by ${ }^{[9]}$ the modification in the test medium (MR-VP broth) incorporates $1 \% \mathrm{NaCl}$, reagent
A consists of 5\% alpha-naphthol in absolute ethanol, and reagent $\mathrm{B}$ is a solution of $0.3 \%$ creatine in $40 \%$ $\mathrm{KOH}$ (potassium hydroxide). The test organism is incubated in MR-VP broth for 48 hours before reagents $\mathrm{A}$ and $\mathrm{B}$ are added. A cherry red color indicates a positive reaction. The results were determined by the ability of the isolated bacteria to produce vp- 1 and vp-2 after addition it depicted the colour change yellow to cherry red color. Ammoniums dehydrogenate phosphate and sodium citrate were used as the sole nitrogen and carbon source respectively. Cholerae species were provided with inorganic ammonium salts as their sole nitrogen source. Metabolism of these salts causes the medium to become alkaline, expressed by a change in colour of the $\mathrm{pH}$ indicator from green to blue. Bromothymolblue used was the $\mathrm{pH}$ indicator. The medium was freshly prepared because in dry conditions, changes in colour may appear even before inoculation, especially at the bottom of the slant. A positive citrate test is reported when there is a change in colour from green to blue of the incubated slant or there is appearance of microbial growth on the slant. [14]

\section{Endonuclease Activity Assay}

Isolation of Lysates and their endonuclease activity The cell lysates were obtained by sonication of bacterial colonies which was already cultured Single bacterial colonies were further cultured for $24 \mathrm{~h}$ in 100$\mathrm{ml}$ Erlenmayer flask containing $20 \mathrm{ml}$ of Luria-Bertani

Aljwadi and Lal
www.apjhs.com


(LB) medium, at $37^{\circ} \mathrm{C}$ with shaking. The elutes obtained according to ${ }^{[10]}$ were analyzed for endonuclease activity by digestion of $\lambda$ DNA and results observed on Agarose Gel as seen in the figure below. Sonication of bacterial cells is known to release various proteins including non-specific nucleases ${ }^{[11]}$ and usually, to achieve high-purity restriction endonucleases, multistep purification on several matrices is used. ${ }^{[12]}$ However, screening for restriction endonuclease activity requires only partial purification. Therefore we followed a partial purification method in this study.

\section{RESULTS AND DISCUSSION}

Out of the different samples 6 different isolates in which 3 from environmental source and three from faecal source were obtained and chosen for Biochemical Tests[Table 1].

Table 1: The Biochemical profile Vibrio species obtained from Water and faecal Sample

\begin{tabular}{|c|l|c|c|c|c|c|c|}
\hline S.No. & \multicolumn{1}{|c|}{ Biochemical test } & Isolate 1 & Isolate 2 & Isolate 3 & $\begin{array}{c}\text { Isolate } \\
\mathbf{4}\end{array}$ & Isolate 5 & Isolate 6 \\
\hline 1 & Glucose & + & + & + & + & + & + \\
\hline 2 & Sucrose & + & + & + & + & - & - \\
\hline 3 & Arginine Hydrolysis Test & - & - & - & - & + & + \\
\hline 4 & Citrate & + & + & + & + & + & + \\
\hline 5 & Indole & + & + & + & + & + & + \\
\hline 6 & V.P. & - & - & + & - & - & - \\
\hline
\end{tabular}

After this Biochemical screening three isolates were chosen and their lysates were prepared and their Endonuclease Assay was performed. The results observed in gel shows that all the three vibrio isolates obtained from water samples possess endonuclease activity varying in the intensity of digestion they showed. Owing to these variations, the reason could be identified as due to lower digestion and activity or the steps in purification process make their intensity lower. As the result in the gel depicts, Lane 2, 10 and 11 with digested sample of Lambda DNA by crude Vibrio extracts of 1_WS, 2_WS, 3_WS showing their endonuclease activity. The digestion pattern for three isolates show very similar pattern. Isolate 1_WS digested the DNA sample into 12 fragments while 2_WS and 3_WS digested it into 11 prominent fragments. Thus in the crude state, both the cell lysates showed similar endonuclease activity when extracted through same process[Fig 2,3].

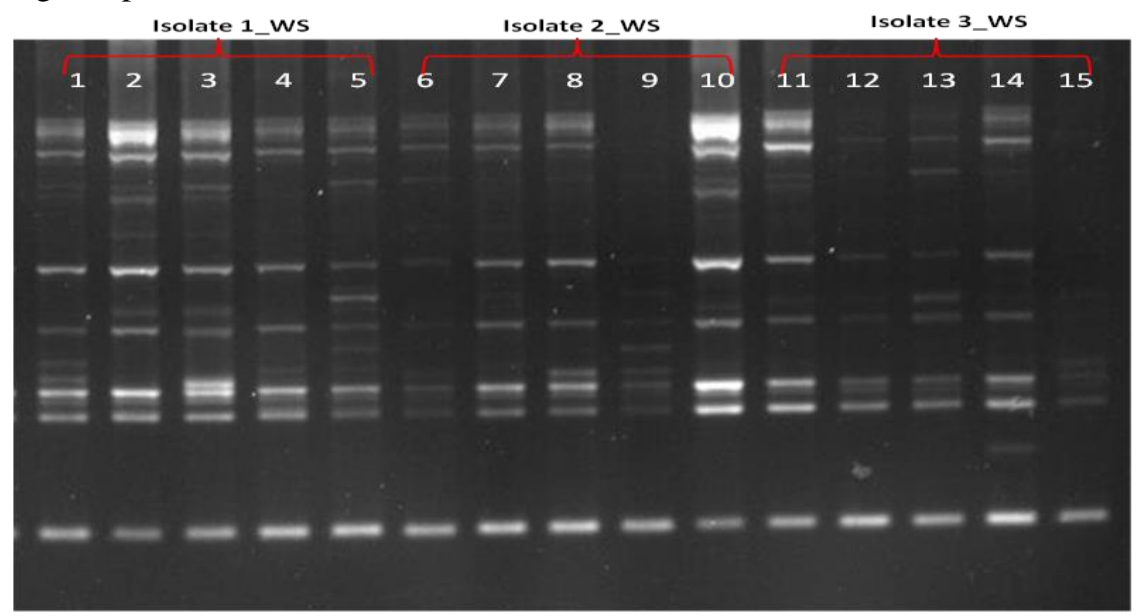

Fig 2: Lane 1-5; Endonuclease activity of Isolate 1 from water sample; Lane 6-10; Endonuclease activity of Isolate 2 from water sample; Lane 11-15; Endonuclease activity of Isolate 3 from water sample. Lane 2,10 and 11: Digested sample of Lambda DNA using crude Vibrio extracts of 1_WS, 2_WS, 3_WS respectively; Lane 1,3,4 and 5: Eluted fractions (F1,F2,F3,F4) of crude cell lysate from 1_WS; Lane 6,7,8 and 9: Eluted fractions $(\mathrm{F} 1, \mathrm{~F} 2, \mathrm{~F} 3, \mathrm{~F} 4)$ of crude cell lysate from 2_WS; Lane 12,13,14 and 15: Eluted fractions (F1,F2,F3,F4) of crude cell lysate from 3_WS

\begin{tabular}{lll}
\hline $\begin{array}{l}\text { Aljwadi and Lal } \\
\text { www.apjhs.com }\end{array}$ & Asian Pacific Journal of Health Sciences, 2019;6(4):5-10 & Page 7 \\
\hline
\end{tabular}




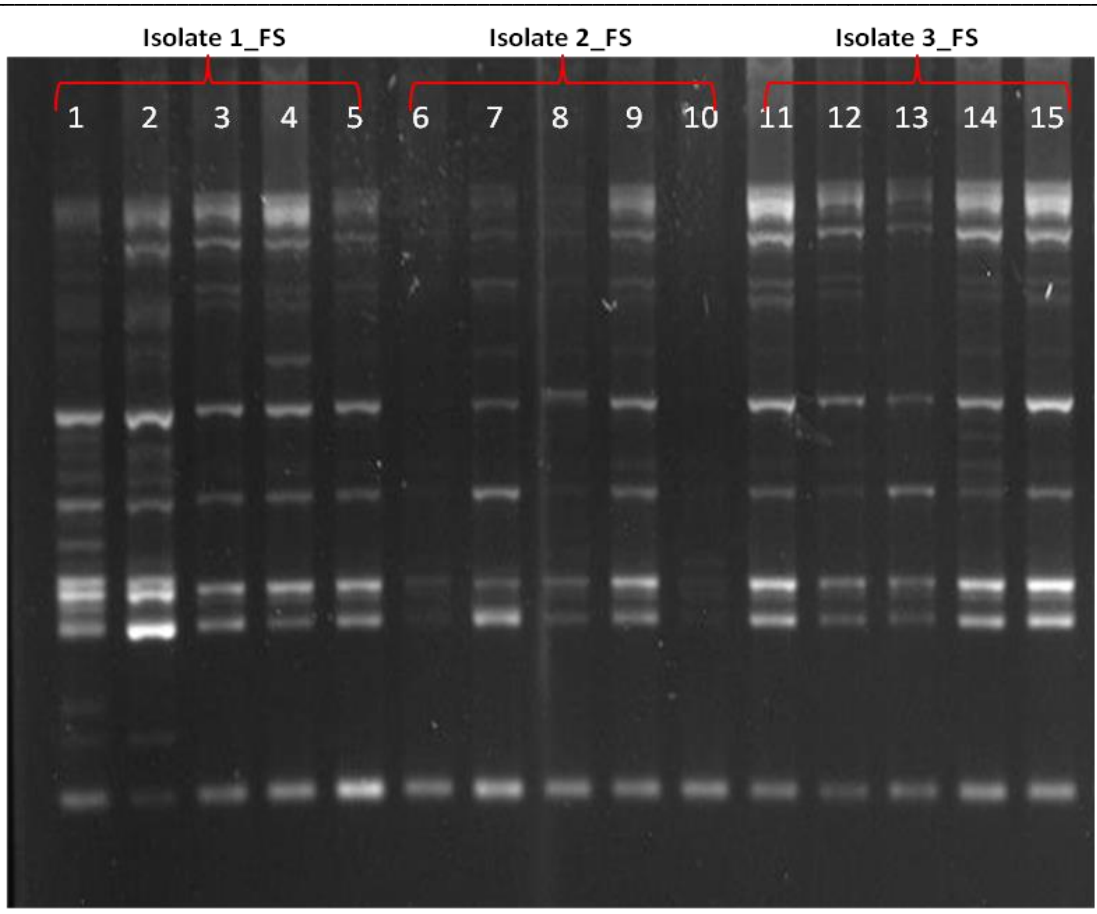

Fig 3: Lane 1-5; Endonuclease activity of Isolate 1 from faecal sample; Lane 6-10; Endonuclease activity of Isolate 2 from Faecal sample; Lane 11-15; Endonuclease activity of Isolate 3 from faecal sample. Lane 2,7 and 11: Digested sample of Lambda DNA using crude Vibrio extracts of 1_FS, 2_FS, 3_FS respectively; Lane 1,3,4 and 5: Eluted fractions $(\mathrm{F} 1, \mathrm{~F} 2, \mathrm{~F} 3, \mathrm{~F} 4)$ of crude cell lysate from 1_FS; Lane 6,8,9 and 10: Eluted fractions (F1,F2,F3,F4) of crude cell lysate from 2_FS; Lane 12,13,14 and 15: Eluted fractions (F1,F2,F3,F4) of crude cell lysate from 3_FS

\section{DISCUSSION}

The six isolates labeled as 1_WS, 2_WS and 3_WS (isolated from water samples) and 1_FS, 2_FS and 3_FS (isolated fromfaecal samples) were analyzed for their endonuclease activity. The endonuclease activity for these isolates was done after preparation of cell free extract and partial purification of these extracts using chromatographic technique. ${ }^{[15]}$ The digestion pattern for three isolates show very similar pattern. ${ }^{[16-17]}$ Isolate 1_WS digested the DNA sample into 12 fragments while 2_WS and 3_WS digested it into 11 prominent fragments. Thus in the crude state, both the cell lysates showed similar endonuclease activity when extracted through same process. The digestion pattern for two isolates (1_FS \& 3_FS) show very similar pattern with non specific digestion while 2_FS show variation in its band pattern with specific endonuclease activity. Isolate 1_FS digested the DNA sample into 13 fragments while 2_FS into 10 fragments and 3_FS digested it into 11 prominent fragments. Thus in the crude state, both the cell lysates showed similar endonuclease activity when extracted through same process. Thus all the 6 isolates showed endonuclease activity in range of low to high. Thus these vibrio species could be potential source of endonuclease enzymes for some industrial processes in near future. A much detailed study with comparative analysis of obtained pattern with commercially available enzymes band pattern would reveal the specific cutting sites and thus their utilization for useful products. Our investigation was set up with the aim to explore vibrio species obtained from clinical and environmental source for their endonuclease activity. However, naturally occurring enzymes are often not suitable for biocatalytic processes without further tailoring or redesign of the enzyme itself in order to fine-tune substrate specificity activity or other key catalytic properties. Therefore, enzymes obtained from these species could be further used in combination to engineered and de no design of enzyme for their better aid in industrial purposes.

\section{CONCLUSION}

The above mentioned research depicts the detailed analysis on vibrio species which was isolated faecal and environmental samples. It has been studied through different researches that environment contains a very

\begin{tabular}{llr}
\hline $\begin{array}{l}\text { Aljwadi and Lal } \\
\text { www.apjhs.com }\end{array}$ & Asian Pacific Journal of Health Sciences, 2019;6(4):5-10 & Page 8 \\
&
\end{tabular}


dense presence of cholera causing vibrio strains and that only a certain subsets of the strains are associated with human disease. The difference in the genetic profile of the clinical strains of the Vibrio species compared with their environmental counterparts was here exploited to trace specific human isolates to vectors of disease and also to allow a better estimation of whether a particular genotype is more often associated with disease or not. Isolation of Vibrio species was performed by taking water sample from river and Faecal matter they were cultured on TCBS Agar plate further they were screened through their biochemical properties. 6 different isolates were chosen to sonicate and bring up the lysates in order to obtain to assay their endonuclease activity, In every nook and cranny endonuclease activity was possessed by each and every isolate1_FS were in 13 fragments ,2 _WS in 10 fragments ,3_FS in 11 fragments. Thus it gave comparative assessment of Restriction endonuclease pattern.

\section{ACKNOWLEDGMENT}

I must express my very profound gratitude to my parents my sisters and my brothers for providing me with unfailing support and continuous encouragement throughout my years of study and through the process of researching and writing this thesis. This accomplishment would not have been possible without them. Thank you. I would also like to express my special appreciation and thanks to my advisor Dr. Sapna Lal Smith from the Faculty of Health and Medical Sciences S.H.U.A.T.S. I would like to thank you for encouraging my research and for allowing me to grow as a research scientist. Your advice on both research as well as on my career have been invaluable. I would like also to thank the Laboratory of the University providing Support with sample and equipment. This work was supported by a grant from the University Sam Higginbottom University of Agriculture, Technology and Sciences.

\section{REFERENCES}

1. Hasan $\mathrm{N}$ A. Comparative genomics of clinical and environmental Vibrio mimicus.Proc Natl Acad Sci USA.2010; 107:21134-21139.

2. Janda, J. M., Power, C., Bryant, R. G., and Abbott, S. L.Current perspectives on the epidemiology and pathogenesis of clinically significant Vibrio spp. Clin. Microbiol. Rev.1988; 1:245-267.
3. Hase, C. C., and Finkelstein, R. A. Bacterial extracellular zinc-containing metalloproteases. Microbiol. Rev.1993; 57: 823-837.

4. Harrington, D. J. Bacterial collagenases and collagen-degrading enzymes and their role in human disease. Infect. Immun.1996; 64:18851891.

5. Nathans D and Smith HO. Restriction endonucleases in the analysis and restructuring of DNA molecules. Annual Review of Biochemistry, 1975; 44: 273-293.

6. Downes F. P. and Ito K., (Eds.) Compendium of Methods for the Microbiological Examination of Foods, 4th Ed., American Public Health Association, Washington, D.C. (2001)

7. Clesceri L. S., Greenberg A. E. and Eaton A. D., (Eds.) Standard Methods for the Examination of Water and Wastewater, 20th Ed., American Public Health Association, Washington, D.C.(1998)

8. Jorgensen JH, Turnidge JD, Washington JA. Antibacterial susceptibility tests: dilution and disk diffusion methods. In: Murray PR, Pfaller MA, Tenover FC, Baron EJ, Yolken RH, ed. Manual of clinical microbiology, 7th ed.. Washington, DC: ASM Press; 1526-1543 (1999).

9. Thornley, M. J. The differentiation of Pseudomonas from other gram-negative bacteria on the basis of arginine metabolism. J. Appl. Bacteriol.1960; 23:37-52.

10. Belavin PA, Dedkov VS, Degtyarew SKh A simple technique for detection of restriction endonucleases in bacterial colonies. Appl Bioch Microbiol (Russia). 1988;24: 121-124.

11. Hasegawa, H., and C. C. Hase. The extracellular metalloprotease of Vibrio tubiashii directly inhibits its extracellular haemo lysin. Microbiology.2009;155:2296-2305.

12. Finkelstein, R.A., Boesman-Finkelstein,M., Chang,Y., and Hase, C. C. Vibrio cholerae hemagglutinin/protease, colonial variation, virulence, and detachment. Infect. Immun.1992; 60, 472-478

13. Smith DI, Blattner FR, Davies $J$ The isolation and partial characterization of a new restriction endonuclease from Providencia stuartii. Nuc Acids Res. 1976; 2: 343-353.

14. Puchkova, L.I. and Serov, G.D., USSR Inventor's Certificate no. 1406159, Byull. Izobret., 1988, no. 24, pp. 92-93.

15. Leal N.C, Araújo Figueiroa "Characterization of Vibrio cholerae isolated from the aquatic basins of the State of Pernambuco, 
Brazil," Transactions of the Royal Society of Tropical Medicine and Hygiene,2008;102:272276.

16. Amon J, Titgemeyer F, BurkovskiA. A genomic view on nitrogen metabolism and nitrogen control in mycobacteria. Journal of Molecular
Microbiology and Biotechnology.2009;17:2029.

17. Puchkova LI, Ushakova TA, Mikhailova VK, Serov GD, Krivopalova GN, Repin VE Testing and isolation of high-purity restriction endo nucleases. Appl Biochem and Microbiol 2002;38: 15-19.

Conflict of Interest: None

Source of Support: Nil 